\title{
THE IMPACT OF CORONAVIRUS PANDEMIC ON THE STOCK MARKET REACTION IN THE BANKING SECTOR. THE ROLE OF REGULATORY AND SUPERVISORY FRAMEWORK ACROSS EUROPEAN UNION MEMBERS
}

\author{
ANDREEA MAURA BOBICEANU ${ }^{\mathrm{i}}$, SIMONA NISTOR ${ }^{\mathrm{ii}}$
}

\begin{abstract}
The purpose of this paper is to assess the impact of COVID-19 outbreak upon the stock prices of the banking sector in the European Union evaluating the responses of banks from different jurisdictions with different regulatory policies and tax regimes. Using an event study technique, we examine the abnormal returns across a significant number of banks. The results show a broadly negative response of the investors to the COVID-19 pandemic official announcement. However, we found significant evidence of differences between banks form distinct jurisdictions. The investors have a stronger negative reaction for the banks from non-euro area, as well as for the banks from peripheral and semiperipheral countries. From a regulatory perspective, the investors have an enhanced adverse reaction for banks in jurisdictions where the activities restrictions and supervisory powers are lower, and where capital requirements are tighter.
\end{abstract}

Keywords: bank stock prices, CDS spreads, event study, abnormal returns.

JEL Classification: $G 21, G 32, G 34$

\section{INTRODUCTION}

In this paper we aim to assess the impact of the coronavirus pandemic upon the stock market returns in the European Union banking sector, using a sample of significant financial institutions from European Union (EU) member countries. The

\footnotetext{
${ }^{\text {i }}$ Babeș-Bolyai University, Postal Adress: Teodor Mihali Street, Nr. 58-60, Cluj-Napoca 400591, Romania, E-mail: maura.bobiceanu@econ.ubbcluj.ro

ii Babeș-Bolyai University, Postal Adress: Teodor Mihali Street, Nr. 58-60, Cluj-Napoca 400591, Romania, E-mail: simona.mutu@econ.ubbcluj.ro
} 
rationale for choosing this theme consists of the importance to provide further evidence on the debate of the economic impact in light of coronavirus pandemic. Although, the repercussions of the pandemic are obvious and have a worldwide negative impact on multiple fields such as education, healthcare, as well as on the entire economy, in this paper we attempt to provide empirical evidence regarding the implications of the pandemic on investors behaviour form the banking sector. It is necessary to establish the extent to which the stock returns in the banking sector are influenced by the coronavirus pandemic announcement as well as the overall investors' reaction.

The methodological approach involves an event study technique using the stock returns of European Union publicly listed banks. Our database comprises the stock returns of 141 banks from 21 member countries of the European Union, for approximately 2 years. The event date for our study is $11^{\text {th }}$ of March 2020, the day World Health Organization declared COVID-19 a pandemic. In order to capture the investors' reaction, we compute the abnormal returns using the market model, as it is one of the largely used models for this purpose, as well as the hybrid Capital Asset Pricing Model, including both regional and global factors, addressing the integration problem. Moreover, we compute the average abnormal returns across countries, we use regulatory and supervisory indices, euro area membership status and the countries' classification in the world-systems theory in order to divide the banks in subsets with different characteristics. The purpose is to identify the differences between banks from distinct EU jurisdictions.

This paper is organized in five sections. Hence the first section contains the introduction, the second section presents the literature review regarding the banking sector's reaction in the context of a pandemic, the third section consists of the event study conducted using the stock returns in the banking sector, the fourth section provides the results of our study, and section five reports the conclusions.

\section{LITERATURE REVIEW}

\subsection{General presentation}

The events that lead to pandemics are recurring biological phenomena and they cannot be realistically prevented. Pandemics seem to occur every 10 or 50 years as a result of new virus subtypes from virus re-assortment (Potter, 2001). However, the rapid spread of the virus and the fast globalization distinguish the coronavirus from other pandemics, leading to uncertainty and consequences on a large scale. Considering the facts stated above, the overall impact of the pandemic 
on the stock market within the banking sector and the spillovers to the entire economy are to be difficult to quantify or predict.

The global uncertainty reached high levels in the beginning of the COVID-19 outbreak. For example, the world uncertainty index - a quarterly measure of the global economic and political uncertainty, which covers 143 countries - indicates that, even though the uncertainty decreased by approximately $60 \%$ from the maximum observed in the beginning of the pandemic, in the first quarter of 2020, it remained with approximately 50\% above the historical average from 1996-2010 (Ahir, Bloom, and Furceri, 2021). The COVID-19 pandemic forced many companies to close, leading to an unprecedented interruption in the majority of industries. Moreover, the COVID-19 pandemic started a sudden "deglobalization" process through lockdown of borders among many countries (Elnahass, Trinh, and $\mathrm{Li}, 2021$ ). The economic repercussions of the COVID-19 pandemic were named "Coronanomics" by Eichengreen (2020). The entire world was hit by a "macroeconomic flu" (Baldwin and Weder di Mauro, 2020), a transient supply and demand shock. The entire world was hit by a "macroeconomic flu" (Baldwin and Weder di Mauro, 2020), a transient supply and demand shock. The economic slowdown was certainly a setback for the corporate sector, forcing the companies to scrape for financial resources to cover the operating costs as a result of revenue shortage.

In light of the unprecedented circumstances, the central banks and the governments adopted a series of policy interventions. While some measures were aimed to reduce the sharp tightening of financial conditions in the short term, others sought to support the flow of credit to firms, either by direct intervention of credit markets (e.g., government sponsors credit lines and liability guarantees), or by relaxing banks' constraints on the use of capital buffers (Demirguc-Kunt, Pedraza, and Ruiz-Ortega, 2020). The majority of the governments responded immediately to manage the economic and financial shocks by providing fiscal, monetary and macro financial stimulus. However, the lockdowns, the postponement of loan payments and the uncertain political perspective increased the systemic vulnerability of the banking sector, especially in emerging countries (Rizwan, Ahmad, and Ashraf, 2020). While the credit institutions are being urged to play an important countercyclical role for the real sector, these measures can also have a series of implications on the banking sector's resilience, for example as the creditors exhaust their existent reserve, this can damage the asst quality, threatening the banking system's stability (Demirguc-Kunt, Pedraza, and Ruiz-Ortega, 2020). 


\subsection{The European Union banking sector and the COVID-19 impact}

Due to the reforms created after the 2008 financial crisis, the European banks were much stronger, more stable at the beginning of the pandemic in comparison with previous financial crisis. The banks' resilience, in this unprecedented economic environment, depends primarily on their access to the central banks' liquidity. ECB replied accordingly to other central banks and avoided the risk of commercial banks' liquidity shortage, but the resilience of the latter depends as well on their loss absorbing capacity and thus on their capital level. (Couppey-Soubeyran, Perego, and Tripier, 2020).

Following the Basel III agreement, signed in 2010 and completed in 2017, the capital requirements were consolidated, liquidity requirements were introduced as well as a new simpler capital rate, not depending on the risk weighted assets. Two new instruments, one adjusting the capital requirements to the financial cycle and the other one to the systemic factor of the institutions added a macro-prudential note to the previous exclusively micro-prudential framework, dedicated to individual risks prevention (credit risk, operational risk) rather than systemic risk prevention.

The European Union temporary adopted a set of rules to maximize the loan activity of the banks and thus to support households and companies recover after the COVID-19 crisis. These changes allowed credit institution to entirely play their part managing the economic shock caused by the COVID-19 crisis, through promoting credit flow. The measures were adopted by the European Parliament on June $24^{\text {th }} 2020$ (Regulation (EU) 2020/873 of the European Parliament and of the Council of $24^{\text {th }}$ June 2020).

\subsection{Stock market evolution during COVID-19}

While the COVID-19 shock was a strong hit for the entire world in the first quarter of 2020, the consequences of the pandemic were rapidly spread to the stock market (Goodell, 2020). The global stock market reacted in a negative manner to the COVID-19 turmoil. For example, S\&P 500, Dow Jones, Russell 2000, Nasdaq Composite, FTSE 100 and Nikkei 225 dropped until the end of March by approximatively 30-40\% from their January values (Elnahass, Trinh, and Li, 2021). The COVID-19 crisis had a major impact on banks all around the world and harmful effects on the stock market. Many of them reported the fastest stock price decline from history.

Actions taken by the governments in order to counter the virus from spreading, such as social distancing and temporary interruption of activity in several industries that are not vital, led to the need of external financing. In this 
setting, the banks played a primary role. Demirguc-Kunt, Pedraza, and RuizOrtega (2020) suggest that the negative impact of COVID-19 shock on banks is stronger and more persistent compared to companies from other industries and other non-bank financial institutions, uncovering the anticipation of banks to absorb at least a part of the shock to the corporate sector. Moreover, larger banks, public banks and, to some extent, better capitalized banks suffer greater reductions in their stock returns, reflecting their greater anticipated role in dealing with the crisis (Demirguc-Kunt, Pedraza, and Ruiz-Ortega, 2020).

\section{DAta AND Methodology}

\subsection{Sample and event date}

We compile a large dataset of banks using stock prices from investing.com. The data consists of daily returns of banks from European Union over approximately 2 years, i.e. 547 trading days, from the beginning of March 2019 to $5^{\text {th }}$ of April 2021. Out of the 158 banks that we initially consider, we decide to eliminate 17 banks that do not have enough data for the case study. The following table reports the countries and the number of banks from each country and the average return of stock prices.

Table 1 The list of countries used in the study

\begin{tabular}{llcc}
\hline Country & Number of banks & Average return $(\%)$ \\
\hline 1. & Austria & 6 & -0.033 \\
2. & Belgium & 1 & -0.006 \\
3. & Bulgaria & 2 & -0.149 \\
4. & Czech Republic & 2 & -0.285 \\
5. & Cyprus & 2 & -0.025 \\
6. & Denmark & 22 & 0.053 \\
7. & Finland & 5 & 0.071 \\
8. & France & 18 & -0.021 \\
9. & Germany & 12 & -0.050 \\
10. & Greece & 6 & 0.079 \\
11. & Ireland & 3 & -0.081 \\
12. & Italy & 17 & 0.020 \\
13. & Malta & 2 & -0.108 \\
14. & Netherlands & 8 & 0.015 \\
15. & Poland & 12 & -0.118 \\
16. & Portugal & 1 & -0.137 \\
17. & Romania & 3 & 0.055 \\
18. & Slovenia & 1 & -0.042
\end{tabular}




\begin{tabular}{llcc}
\hline \multicolumn{2}{l}{ Country } & Number of banks & Average return $(\%)$ \\
\hline 19. & Spain & 8 & -0.051 \\
20. & Sweden & 8 & 0.026 \\
21. & Hungary & 2 & -0.003 \\
\hline
\end{tabular}

In the event study methodology, the timeline is made of the event date, estimation window and observation period, including different event windows. The event date is often called day 0 , which represents the date of the event in question appearance. Generally, it is described as the first public announcement of the event. As the event studies are based on the assumption of market efficiency, any information arising from a specific event is rapidly incorporated in the stock price, after the first official announcement. On January $7^{\text {th }} 2020$ the Chinese authorities identify the novel coronavirus temporarily named "2019-nCoV", on January $13^{\text {th }}$ the first case of coronavirus outside of China is reported, on January $30^{\text {th }}$ World Health Organization declares the outbreak a public health emergency of international concern, following that on $11^{\text {th }}$ of March 2020 to be declared a pandemic by WHO Director-General. Considering this timeline, we choose to use $11^{\text {th }}$ of March as the event date of the current study.

\subsection{Abnormal return computation}

Using an event study approach, we measure the differences between the expected returns of stock prices and the actual returns. In literature the difference resulted is called abnormal return excess return, prediction error or residual (Skrepnek and Lawson, 2001). If no abnormal price movement occurs until the event date, the expected abnormal return should fluctuate randomly around zero. Contrarily, if there is a market response to the event, the abnormal returns should become measurable on the defined event date.

There are several methods for abnormal return estimation. In literature the most used models for computing abnormal returns are the market model, the Capital Asset Pricing Model, and the Fama and French factor models. As main technique for expected return estimation we use the market model, employing the following equation:

$$
R_{i t}=\alpha_{i}+\beta_{i} R_{m t}+\varepsilon_{i t}
$$

where $R_{i t}$ is the log-return of bank $i$ 's stock price at a time $t, \alpha_{i}$ is the constant term, $\beta_{i}$ is the slope, $R_{m t}$ is the market portfolio log-return at time $t$ and $\varepsilon_{i t}$ is the iid error term. As market portfolio we use Euro STOXX50 index. 
Through the market model inherent assumptions, the company-specific return is independent of the global market return and has an expected value of zero. Therefore, the expected return on the day of the event, conditioned by the market return is:

$$
E\left(R_{0} \mid R_{m 0}\right)=\alpha_{i}+\beta_{i} R_{m 0}
$$

Adjusting the actual return by subtracting the expected return we obtain the abnormal return. For every bank $i$ at a time $t$ we determine the abnormal return using the following equation:

$$
A R_{i t}=R_{i t}-\left(\alpha_{i}+\beta_{i} R_{m t}\right)
$$

Where $A R_{i t}$ is the abnormal return of bank $i$ at a time $t$. A positive abnormal return shows an actual return greater than the predicted one, which translates as a positive reaction of the investors and the bank's market value increases, whereas a negative abnormal return reflects an actual return smaller than the expected return. In this case the investors' reaction is negative and the market value of the bank declines.

Following the methodology used by Andries, Nistor, Ongena, and Sprincean (2020), we employ as robustness the hybrid CAPM model proposed by Bekaert, Hodrick, and Zhang (2009). This model takes into account the market integration aspect, allowing for exposure to regional and global factors at the same time. Considering the fact that our sample contains banks from Europe, we use the MSCI world index to account for the global factor and the Euro STOXX 50 to account for the regional factor employing the following equation:

$$
R_{i t}-r_{f t}=\alpha_{i}+\beta_{i}\left(R_{m t_{1}}-r_{f t}\right)+\delta_{i}\left(R_{m t_{2}}-r_{f t}\right)+\varepsilon_{i t}
$$

where $R_{i t}-r_{f t}$ is the excess log-return of bank $i$ at time $t, \alpha_{i}$ is the intercept, $R_{m t_{1}}-r_{f t}$ is the excess log-return of MSCI world index at time $t$, $R_{m t_{2}}-r_{f t}$ is the excess log-return of Euro STOXX 50, $r_{f t}$ is the risk-free rate, and $\varepsilon_{i t}$ is the error term which is assumed to be independent and identically distributed (iid) with a mean of zero and a constant variance. As the risk-free rate we employ the one-month Euro Interbank Offered Rate (1M EURIBOR).

To compute the abnormal return, we use the next equation:

$$
A R_{i t}=R_{i t}-r_{f t}-\left[\alpha_{i}+\beta_{i}\left(R_{m t_{1}}-r_{f t}\right)+\delta_{i}\left(R_{m t_{2}}-r_{f t}\right)\right]
$$

where $A R_{i t}$ is the abnormal return of bank $i$ at a time $t$. 
Based on this output we compute the average abnormal return (AAR), the cumulative abnormal return (CAR) and the cumulative average return (CAAR). First, we compute the average abnormal return following Brown and Warner (1985):

$$
A A R_{T}=\frac{1}{N} \sum_{i=1}^{N} A R_{i t}
$$

Second, to assess the tock reaction over a time frame we sum the abnormal returns in any interval in the event window $\left(\left[t_{1} ; t_{2}\right]\right)$ in order to obtain the cumulative average return as in Morgan. Peristiani, Savino (2014):

$$
C A R_{i}\left[t_{1} ; t_{2}\right]=\sum_{t=t_{1}}^{t_{2}} A R_{i t}
$$

Third, we compute the cumulative average abnormal return using the formula proposed by MacKinlay (1997):

$$
C A A R\left[t_{1} ; t_{2}\right]=\sum_{t=t_{1}}^{t_{2}} A A R_{t}
$$

In our event study we use an estimation window of 250 trading days, from day -260 to day $-11([-260 ;-11])$, where $T=0$ is the event day. MacKinlay (1997) suggests that this interval is sufficient to conduct an event study using daily data. To measure the abnormal returns, we consider multiple event windows to capture the immediate effects: $[-1 ; 1],[-3 ; 3],[-5 ; 5],[0 ; 0]$, as well as the changes following the event: $[1 ; 1],[1 ; 5]$.

We test the significance of CARs using the t test., which is one of the most popular tests employed in the literature on event studies.

\subsection{Regulatory and supervisory factors}

Our case study involves two perspectives, the first one includes the consequences of the pandemic on the banks' stock prices and the second one combines the data regarding the stock prices and publicly available data about regulatory and supervisory framework. For a better understanding of the results and the implications of the regulation, we analyse in cross-section the abnormal returns, grouping the banks with respect to several the regulatory indices and tax regimes. In this manner we are not only examining the overall response to the event, but we report the differences between groups of banks with different regulatory positions.

One of the reasons for turning our attention towards banking regulations and supervision comes from the fact that all crises reveal a sign of regulation and supervisory issues. An example is the global financial crisis from 2007-2009, resulting in banking problems that still affected the banks in 2013 and over 100 
other systemic banking crisis which devastated economies around the world since 1970 (Barth, Caprio Jr., Levine, 2013). There are four versions of the survey covering the period 1999-2012. Since the country level regulation variables measure different levels from one period to another, we use the most recent survey, the one from 2013.

In order to account for these differences, we use bank regulatory and supervisory police measures provided by Barth, Caprio Jr. and Levine (2013) in a public database based upon responses to hundreds of questions. The indices we employ in our study are:

- overall activity restriction index - measures the extent to which the bank can engage in securities transactions, real estate transactions, insurance activities and the possibility of owning nonfinancial firms, higher values indicating grater restrictiveness;

- supervisory power index - measures the degree to which the supervisory authorities have the power to take specific action for preventing and correcting reasons, higher values indicating grater supervisory power;

- overall capital stringency - measures whether the capital requirements reflect certain risks and deducts certain market value losses before determining minimum capital adequacy, higher value meaning grater stringency (Barth, Caprio Jr., Levine, 2013)

To allow comparisons between countries with different bank regulation levels, we group them in two subgroups using the median for each index leading to six subgroups: countries with lower/higher overall activity restrictions; countries with lower/higher supervisory power and countries with lower/higher overall capital stringency.

The table reports the indices values provided by the World Bank (Bank Regulation and Supervision Survey) for each country. The first column reports the country, the second column reports the overall activity restriction index values, the third column reports the supervisory power values and the last column reports the overall capital stringency values.

Table 2 Regulatory and supervisory indices

\begin{tabular}{lccc}
\hline Country & $\begin{array}{c}\text { Overall activity } \\
\text { restriction index }\end{array}$ & $\begin{array}{c}\text { Supervisory power } \\
\text { index }\end{array}$ & $\begin{array}{c}\text { Overall capital stringency } \\
\text { index }\end{array}$ \\
\hline Austria & 4 & 12 & 2 \\
Belgium & 5 & 11 & 5 \\
Bulgaria & 5 & 11 & 6 \\
Cyprus & 7 & 11 & 6 \\
Czech Republic & - & - & -
\end{tabular}




\begin{tabular}{lccc}
\hline Country & $\begin{array}{c}\text { Overall activity } \\
\text { restriction index }\end{array}$ & $\begin{array}{c}\text { Supervisory power } \\
\text { index }\end{array}$ & $\begin{array}{c}\text { Overall capital stringency } \\
\text { index }\end{array}$ \\
\hline Denmark & 7 & 11 & 4 \\
Finland & 5 & 5 & 5 \\
France & 8 & 10 & 6 \\
Germany & - & 11 & 6 \\
Greece & 6 & 8 & 6 \\
Hungary & 5 & 13 & 2 \\
Ireland & 4 & 6 & 7 \\
Italy & 7 & 13 & 5 \\
Malta & 8 & 12 & 6 \\
Netherlands & 5 & 11 & 6 \\
Poland & 11 & 11 & 6 \\
Portugal & 5 & 12 & 2 \\
Romania & 4 & 12 & 6 \\
Slovenia & 6 & 14 & 5 \\
Spain & 5 & 9 & 6 \\
Sweden & - & - & - \\
\hline
\end{tabular}

\subsection{Tax regimes}

Regarding the tax regime, we choose to divide the countries using two criteria: the eurozone membership and the world-systems theory position. At this moment, 19 countries out of 27 are members of Eurozone. In our sample, the Eurozone members are: Austria; Belgium; Cyprus; Finland; France; Germany; Greece; Ireland; Italy; Malta; Netherlands; Portugal; Slovenia; Spain. The countries in our sample outside the Eurozone are: Bulgaria; Czech Republic; Denmark; Poland; Romania; Sweden; Hungary. Thus, we grouped the banks in these categories according to the country they belong to.

In line with the world-systems theory, we group the countries in two subgroups: core countries and periphery or semi-periphery countries. The core countries are wealthy, industrialized countries that periphery and semi-periphery countries depend on. The countries from our sample belonging to this group are, according to Chase-Dunn, Kawano, Brewer (2000): Austria; Belgium; Denmark; Finland; France; Germany; Ireland; Italy; Netherlands; Portugal; Spain; Sweden and the periphery and semi-periphery countries are: Bulgaria; Czech Republic; Cyprus; Greece; Malta; Poland; Romania; Slovenia and Hungary. 


\section{RESUlts}

\subsection{Descriptive statistics}

Descriptive statistics reported in Table 3 indicate an average return over the period selected for the study of $-0,01 \%$ with a minimum return of $-251,80 \%$, a maximum of $274,08 \%$ and a standard deviation of $3,19 \%$. Table 4 reports descriptive statistics over the period before the official announcement of the pandemic as well as over the period after the announcement. The average return before de announcement is $-0,08 \%$ and after the announcement it reaches $0.05 \%$. Although the average return shows an increased value, it also reports a higher standard deviation from $2,57 \%$ to $3,68 \%$ indicating a higher risk. The minimum value before the event is $-25,60 \%$ and after the event it is $-251,80 \%$ and regarding the maximum values, before the event the value is $274,08 \%$ and after the event the value being $83,41 \%$.

The table reports descriptive statistics for the daily returns for the banks included in our sample.

Table 3 Descriptive statistics for the entire sample

\begin{tabular}{llllll}
\hline Variable & $\mathrm{N}$ & Mean & Std. Dev. & Min & Max \\
\hline Return & 72,877 & -0.0001 & 0.0319 & -2.5180 & 2.7408 \\
\hline
\end{tabular}

The table reports descriptive statistics for daily returns of banks included in our sample by variable Dummy COVID. The variable takes value of 0 for the period before the event and the value of 1 for the event day and after the event.

Table 4 Descriptive statistics before and after the announcement

\begin{tabular}{llllll}
\hline Dummy COVID & N & Mean & SD & Min & Max \\
\hline 0 & 35576 & -0.0008 & 0.0257 & -0.2560 & 2.7408 \\
1 & 37301 & 0.0005 & 0.0368 & -2.5180 & 0.8341 \\
$\begin{array}{l}\text { The difference between returns } \\
\text { before and after the COVID event } \\
\text { p-value }\end{array}$ & & -0.0013 & 0.0002 & & \\
\hline
\end{tabular}

\subsection{Cumulated average abnormal returns}

Table 5 reports the average abnormal returns cumulated for all of the 141 banks within our sample. We use both the Market Model and the Capital Asset 
Pricing Model to compute the abnormal returns, thus we report the results for both methods in Table 5.

This table reports the cumulated average abnormal returns and the p-values for six event windows.

Table 5 Cumulated average abnormal returns

\begin{tabular}{lcccccc} 
& $\begin{array}{c}\text { CAAR } \\
(-1,1)\end{array}$ & $\begin{array}{c}\text { CAAR } \\
(-3,3)\end{array}$ & $\begin{array}{c}\text { CAAR } \\
(-5,5)\end{array}$ & $\begin{array}{c}\text { CAAR } \\
(0,0)\end{array}$ & $\begin{array}{c}\text { CAAR } \\
(1,1)\end{array}$ & $\begin{array}{c}\text { CAAR } \\
(1,5)\end{array}$ \\
\hline CAAR & $-0.0513^{* * *}$ & $-0.1236^{* * *}$ & $-0.1612^{* * *}$ & $-0.0120^{* * *}$ & $-0.0474^{* * * *}$ & $-0.0903^{* * *}$ \\
$(\mathrm{MM})$ & 0.0000 & 0.0000 & 0.0000 & 0.0000 & 0.0000 & 0.0000 \\
CAAR & $-0.0464^{* * *}$ & $-0.1081^{* * *}$ & $-0.1465^{* * *}$ & -0.0013 & $-0.0429^{* * *}$ & $-0.0782^{* * *}$ \\
$($ Hybrid CAPM) & 0.0000 & 0.0000 & 0.0000 & 0.5207 & 0.0000 & 0.0000 \\
\hline
\end{tabular}

The cumulated average abnormal returns are useful for studying the aggregate results of abnormal returns over the entire sample or over sub-samples. Table 5 shows the average abnormal returns over the whole sample along with the associated p-values in order to express the significance of the results. The CAARs are reported for the six event windows that were used for computing the abnormal returns: $[-1 ; 1],[-3 ; 3],[-5 ; 5],[0 ; 0],[1 ; 1]$ and $[1 ; 5]$. The CAARs for event window $[0 ; 0]$ and $[1 ; 1]$ are the cumulated average abnormal returns on the event day and the day after.

On all of the event windows considered in the study, including the event day ( $11^{\text {th }}$ of March 2020), the day the COVID-19 pandemic was announced, the market has a negative reaction, indicating a pessimistic behaviour of investors. The remark stated before results from the negative sign of the CAARs, which are also significant over all windows. These results and interpretations are valid for the CAARs calculated using the market model, as well as for the ones calculated with the hybrid CAPM. The CAARs obtained are similar for both methods of estimation.

The results indicate a "stigma effect" generated by the official announcement of the pandemic. The market participants perceive the announcement as a threat for the banks, thus the investors' wealth suffer a drop. Investors' reaction does not occur only on the event day, the negative reaction before the announcement indicating an anticipation of the event, potentially caused by the increasing number of the coronavirus cases all over the globe. 


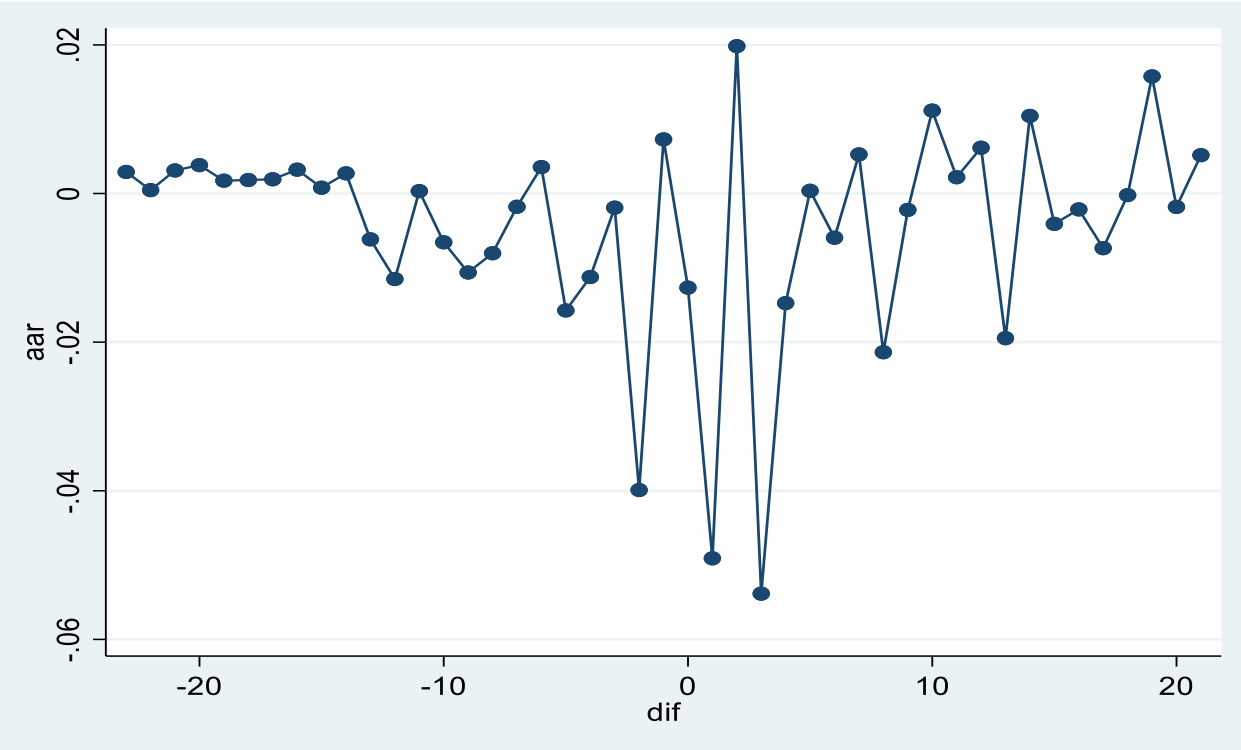

Figure 1 Average abnormal returns

The figure shows the evolution of average abnormal returns over the event window $[-20 ; 20]$, day 0 being the day of the official announcement of coronavirus pandemic. The abnormal returns are computed using the market model.

The graphic representation above denotes an increased volatility of average abnormal returns around day 0 . Moreover, we can note that before February $25^{\text {th }}$, the average abnormal returns fluctuate around the value 0 and after that day the volatility starts increasing, reaching an extreme volatility around the official announcement day. The fluctuation that starts on February $25^{\text {th }}$ can be explained by the Centers for Disease Control and Prevention announcement which detailed the characteristics of a pandemic and specified that the COVID-19 epidemy will perhaps classify as a pandemic.

\subsection{Comparisons between cumulated average abnormal returns at country level}

We conduct this study using European Union countries, so we consider appropriate a comparison between each country. In order to reflect the differences, we calculate the cumulated average abnormal return for every country.

The table reports the CAARs for each country for the six event windows ${ }^{1}$.

\footnotetext{
${ }^{1}$ For the same sample, we ran the hybrid CAPM and we obtained similar results.
} 
Table 6 Cumulated average abnormal returns at country level using the market model

\begin{tabular}{|c|c|c|c|c|c|c|}
\hline & $\begin{array}{c}\text { CAAR } \\
(-1,1)\end{array}$ & $\begin{array}{c}\text { CAAR } \\
(-3,3)\end{array}$ & $\begin{array}{c}\text { CAAR } \\
(-5,5)\end{array}$ & $\begin{array}{c}\text { CAAR } \\
(0,0)\end{array}$ & $\begin{array}{c}\text { CAAR } \\
(1,1)\end{array}$ & $\begin{array}{c}\text { CAAR } \\
(1,5)\end{array}$ \\
\hline \multirow[t]{2}{*}{ Austria } & $-0.0668^{* * * *}$ & $-0.1550^{* * * *}$ & $-0.2715^{* * * *}$ & $-0.0254^{* * * *}$ & $-0.0489^{* * * *}$ & $-0.2094^{* * * *}$ \\
\hline & 0.0000 & 0.0000 & 0.0000 & 0.0001 & 0.0000 & 0.0000 \\
\hline \multirow[t]{2}{*}{ Belgium } & -0.0114 & $-0.1088^{* * * *}$ & -0.0092 & 0.0122 & $-0.0629^{* * *}$ & $-0.0889^{* * * *}$ \\
\hline & 0.6088 & 0.0049 & 0.8404 & 0.2616 & 0.0000 & 0.0023 \\
\hline \multirow[t]{2}{*}{ Bulgaria } & $-0.1422^{* * *}$ & $-0.4482^{* * *}$ & $-0.5632^{* * *}$ & -0.0160 & $-0.1305^{* * *}$ & $-0.3653^{* * * *}$ \\
\hline & 0.0003 & 0.0000 & 0.0000 & 0.4008 & 0.0000 & 0.0000 \\
\hline \multirow[t]{2}{*}{ Czech Republic } & $-0.0559^{* * *}$ & $-0.1890^{* * *}$ & $-0.3550^{* * * *}$ & $-0.0166^{*}$ & $-0.0437^{* * *}$ & $-0.2986^{* * *}$ \\
\hline & 0.0018 & 0.0000 & 0.0000 & 0.0551 & 0.0003 & 0.0000 \\
\hline \multirow[t]{2}{*}{ Cyprus } & $-0.0658^{* *}$ & $-0.3317^{* * *}$ & $-0.4024^{* * * *}$ & 0.0163 & $-0.0872^{* * *}$ & $-0.2692^{* * * *}$ \\
\hline & 0.0324 & 0.0000 & 0.0000 & 0.2736 & 0.0000 & 0.0000 \\
\hline \multirow[t]{2}{*}{ Denmark } & $-0.0534^{* * *}$ & $-0.1143^{* * *}$ & $-0.1380^{* * * *}$ & $-0.0116^{* *}$ & $-0.0426^{* * *}$ & $-0.0806^{* * * *}$ \\
\hline & 0.0000 & 0.0000 & 0.0000 & 0.0401 & 0.0000 & 0.0000 \\
\hline \multirow[t]{2}{*}{ Finland } & $-0.1348^{* * *}$ & $-0.2322^{* * *}$ & $-0.2707^{* * *}$ & $-0.0485^{* * *}$ & $-0.0700^{* * *}$ & $-0.1358^{* * * *}$ \\
\hline & 0.0000 & 0.0000 & 0.0000 & 0.0000 & 0.0000 & 0.0000 \\
\hline \multirow[t]{2}{*}{ France } & $-0.0657^{* * * *}$ & $-0.2142^{* * * *}$ & $-0.2276^{* * * *}$ & -0.0065 & $-0.0686^{* * * *}$ & $-0.1355^{* * * *}$ \\
\hline & 0.0000 & 0.0000 & 0.0000 & 0.1987 & 0.0000 & 0.0000 \\
\hline \multirow[t]{2}{*}{ Germany } & -0.0239 & -0.0443 & $-0.0883^{* * * *}$ & -0.0060 & $-0.0291^{* * * *}$ & $-0.0616^{* * *}$ \\
\hline & 0.1442 & 0.1162 & 0.0090 & 0.4483 & 0.0088 & 0.0040 \\
\hline \multirow[t]{2}{*}{ Greece } & 0.0690 & -0.0895 & -0.2218 & $-0.0590^{*}$ & 0.0193 & -0.0898 \\
\hline & 0.3465 & 0.4776 & 0.1412 & 0.0982 & 0.6955 & 0.3462 \\
\hline \multirow[t]{2}{*}{ Ireland } & $0.0901^{* *}$ & 0.0014 & $-0.2330^{* * * *}$ & 0.0205 & 0.0153 & $-0.2461^{* * * *}$ \\
\hline & 0.0226 & 0.9835 & 0.0042 & 0.2849 & 0.5633 & 0.0000 \\
\hline \multirow[t]{2}{*}{ Italy } & $-0.0359^{*}$ & -0.0023 & -0.0542 & $0.0188^{* *}$ & $-0.0294^{* *}$ & 0.0391 \\
\hline & 0.0642 & 0.9456 & 0.1725 & 0.0461 & 0.0247 & 0.1202 \\
\hline \multirow[t]{2}{*}{ Malta } & -0.0352 & -0.0432 & $-0.1405^{* *}$ & 0.0058 & $-0.0314^{*}$ & $-0.1139^{* * * *}$ \\
\hline & 0.1887 & 0.3481 & 0.0112 & 0.6551 & 0.0830 & 0.0012 \\
\hline \multirow[t]{2}{*}{ Netherlands } & $-0.0484^{* * *}$ & $-0.1364^{* * *}$ & $-0.1540^{* * *}$ & 0.0001 & $-0.0444^{* * *}$ & $-0.1113^{* * *}$ \\
\hline & 0.0002 & 0.0000 & 0.0000 & 0.9842 & 0.0000 & 0.0000 \\
\hline \multirow[t]{2}{*}{ Poland } & $-0.1428^{* * * *}$ & $-0.2155^{* * *}$ & $-0.1644^{* * * *}$ & $-0.0618^{* * * *}$ & $-0.0971^{* * * *}$ & -0.0229 \\
\hline & 0.0000 & 0.0000 & 0.0006 & 0.0000 & 0.0000 & 0.4439 \\
\hline \multirow[t]{2}{*}{ Portugal } & $0.1302^{* * *}$ & 0.0159 & -0.0137 & 0.0004 & $0.0675^{* * *}$ & 0.0388 \\
\hline & 0.0002 & 0.7853 & 0.8451 & 0.9796 & 0.0036 & 0.3815 \\
\hline \multirow[t]{2}{*}{ Romania } & $-0.0607^{* * *}$ & $-0.1612^{* * *}$ & $-0.1922^{* * *}$ & $-0.0464^{* * * *}$ & $-0.0349^{* * *}$ & $-0.0873^{* * *}$ \\
\hline & 0.0005 & 0.0000 & 0.0000 & 0.0000 & 0.0028 & 0.0001 \\
\hline
\end{tabular}




\begin{tabular}{|c|c|c|c|c|c|c|}
\hline & $\begin{array}{c}\text { CAAR } \\
(-1,1)\end{array}$ & $\begin{array}{c}\text { CAAR } \\
(-3,3) \\
\end{array}$ & $\begin{array}{c}\text { CAAR } \\
(-5,5)\end{array}$ & $\begin{array}{c}\text { CAAR } \\
(0,0)\end{array}$ & $\begin{array}{c}\text { CAAR } \\
(1,1) \\
\end{array}$ & $\begin{array}{c}\text { CAAR } \\
(1,5) \\
\end{array}$ \\
\hline \multirow[t]{2}{*}{ Spain } & -0.0276 & $-0.1001^{* *}$ & $-0.1346^{* * * *}$ & $0.0198^{*}$ & $-0.0475^{* * *}$ & $-0.1093^{* * *}$ \\
\hline & 0.2249 & 0.0110 & 0.0042 & 0.0738 & 0.0022 & 0.0003 \\
\hline \multirow[t]{2}{*}{ Slovenia } & $-0.1018^{* * * *}$ & $-0.3029^{* * * *}$ & $-0.3381^{\text {*** }}$ & $-0.0221^{* *}$ & $-0.0997^{* * *}$ & $-0.2310^{* * * *}$ \\
\hline & 0.0000 & 0.0000 & 0.0000 & 0.0499 & 0.0000 & 0.0000 \\
\hline \multirow[t]{2}{*}{ Sweden } & $-0.0650^{\text {**** }}$ & $-0.1026^{* * * *}$ & $-0.1502^{* * *}$ & -0.0038 & $-0.0587^{* * *}$ & $-0.1380^{* * * *}$ \\
\hline & 0.0009 & 0.0022 & 0.0002 & 0.6819 & 0.0000 & 0.0000 \\
\hline \multirow[t]{2}{*}{ Hungary } & $-0.1845^{* * *}$ & $-0.2970^{* * * *}$ & $-0.3472^{* * * *}$ & $-0.0960^{* * * *}$ & $-0.1050^{* * *}$ & $-0.2027^{* * *}$ \\
\hline & 0.0000 & 0.0000 & 0.0000 & 0.0000 & 0.0000 & 0.0000 \\
\hline
\end{tabular}

Markets from Austria, Czech Republic, Cyprus, Denmark, Finland, Romania, Slovenia and Hungary have negative CAARs over the six event windows, meaning that the investors on these markets have a negative reaction. The Belgium market reports negative but statistically non-significant CAARs on the following windows: $[-1 ; 1],[-5 ; 5],[0 ; 0]$. The results for both Bulgaria and France are negative and statistically significant except for the event day. Germany reports negative but statistically non-significant results on $[-1 ; 1],[-3 ; 3],[0 ; 0]$ event windows. Greece has a single statistically significant result, representing the event day and it shows a negative reaction. Ireland presents positive CAARs but statistically significant only on $[-1 ; 1]$, on event windows [-5;5], [1;5], indicating a longer term, the results are negative. The Italian capital market reveals positive significant results on the vent day and negative on $[-1 ; 1]$ and $[1 ; 1]$ windows. Malta and Netherlands note negative CAARs except for the event day when the results are positive but statistically non-significant. Poland has negative and statistically significant CAARs except for the last event window and Sweden reports a negative and significant CAARs except the event day. Regarding Portugal, there are only two statistically significant CAARs on [-1;1] and [1;1]. In Spain, the market shows a negative reaction on all of the windows, except for the event day.

\subsection{Comparisons between average abnormal returns by tax regimes}

Regarding the tax regime, we decide to divide the sample by two criteria: eurozone membership and the position of each country in the world-systems theory. Eurozone consists of the countries from European Union that use euro (EUR) as the official currency. In the world-systems theory the countries cand be separated in three main groups: core countries, periphery countries and semiperiphery countries. For simplifying the interpretation of our results, we separated them in two groups, combining the last two divisions into one. 
The table reports cumulated average abnormal returns for the sub-groups divided by the two criteria: eurozone membership and the world-systems theory. On the columns are presented the CAARs for each event window. The estimation model used is the market model ${ }^{1}$.

Table 7 Cumulated average abnormal returns by tax regime using the market model

\begin{tabular}{|c|c|c|c|c|c|c|}
\hline & $\begin{array}{c}\text { CAAR } \\
(-1,1)\end{array}$ & $\begin{array}{l}\text { CAAR } \\
(-3,3)\end{array}$ & $\begin{array}{l}\text { CAAR } \\
(-5,5)\end{array}$ & $\begin{array}{c}\text { CAAR } \\
(0,0)\end{array}$ & $\begin{array}{l}\text { CAAR } \\
(1,1)\end{array}$ & $\begin{array}{c}\text { CAAR } \\
(1,5)\end{array}$ \\
\hline \multicolumn{7}{|l|}{ Euro vs. Non-euro } \\
\hline \multirow[t]{2}{*}{ Eurozone countries } & $-0.0220^{*}$ & $-0.1216^{* * *}$ & $-0.1798^{* * *}$ & -0.0053 & $-0.0356^{* * *}$ & $-0.1214^{* * *}$ \\
\hline & 0.0644 & 0.0000 & 0.0000 & 0.3614 & 0.0000 & 0.0000 \\
\hline \multirow[t]{2}{*}{ Non-eurozone countries } & $-0.1003^{* * *}$ & $-0.2176^{* * *}$ & $-0.2725^{* * *}$ & $-0.0360^{* * *}$ & $-0.0730^{* * *}$ & $-0.1704^{* * *}$ \\
\hline & 0.0000 & 0.0000 & 0.0000 & 0.0000 & 0.0000 & 0.0000 \\
\hline \multirow{3}{*}{$\begin{array}{l}\text { Difference (eurozone } \\
\text { countries - non-eurozone } \\
\text { countries) }\end{array}$} & & & & & & \\
\hline & $-0.0491^{\cdots}$ & -0.0488 & -0.0159 & -0.0239 & -0.0229 & -0.0056 \\
\hline & 0.0008 & 0.0397 & 0.5840 & 0.0002 & 0.0216 & 0.8179 \\
\hline \multicolumn{7}{|l|}{$\begin{array}{l}\text { Core countries vs. } \\
\text { periphery and semi- } \\
\text { periphery countries }\end{array}$} \\
\hline \multirow[t]{2}{*}{ Core countries } & $-0.0252^{* *}$ & $-0.0976^{* * *}$ & $-0.1434^{* * *}$ & -0.0025 & $-0.0342^{* * *}$ & $-0.1021^{* * *}$ \\
\hline & 0.0361 & 0.0000 & 0.0000 & 0.6687 & 0.0000 & 0.0000 \\
\hline \multirow{2}{*}{$\begin{array}{l}\text { Periphery and semi- } \\
\text { periphery countries }\end{array}$} & $-0.0808^{* * *}$ & $-0.2327^{* * *}$ & $-0.3045^{* * *}$ & $-0.0328^{* * * *}$ & $-0.0686^{* * *}$ & $-0.1878^{* * *}$ \\
\hline & 0.0000 & 0.0000 & 0.0000 & 0.0000 & 0.0000 & 0.0000 \\
\hline \multirow[t]{2}{*}{$\begin{array}{l}\text { Difference (core } \\
\text { countries - periphery and } \\
\text { semi-periphery countries) }\end{array}$} & $-0.0331^{*}$ & $-0.0948^{* * *}$ & $-0.0947^{* * *}$ & $-0.0430^{* * *}$ & $-0.0197^{*}$ & -0.0284 \\
\hline & 0.0525 & 0.0004 & 0.0039 & 0.0000 & 0.0874 & 0.3091 \\
\hline
\end{tabular}

Table 7 shows that, on short term, there are statistically significant differences between CAARs of eurozone banks and non-eurozone banks, hence the differences are statistically significant on all of the windows except $[-5 ; 5]$ and $[1 ; 5]$. The CAARs although negative in both cases, are stronger for non-eurozone banks. These phenomena can be explained by the investors' expectations that eurozone banks will receive more support from the European Central Bank relative to non-eurozone banks. The fact that on the $[-5 ; 5]$ and $[1 ; 5]$ event windows, the differences are statistically non-significant proves that on a long term, the investors react in a similar manner regardless of the eurozone membership.

\footnotetext{
${ }^{1}$ Using the same sub-samples, we ran the hybrid CAPM and the results remained similar.
} 
Concerning the position in the world-systems theory, there are statistically significant differences. The investors have an enhanced adverse reaction in the case of banks from periphery and semi-periphery countries compared to the ones from core countries. However, on a longer term, after the event day, there are no statistically significant differences.

Panel A. AARs in periphery and semi-periphery countries versus core countries
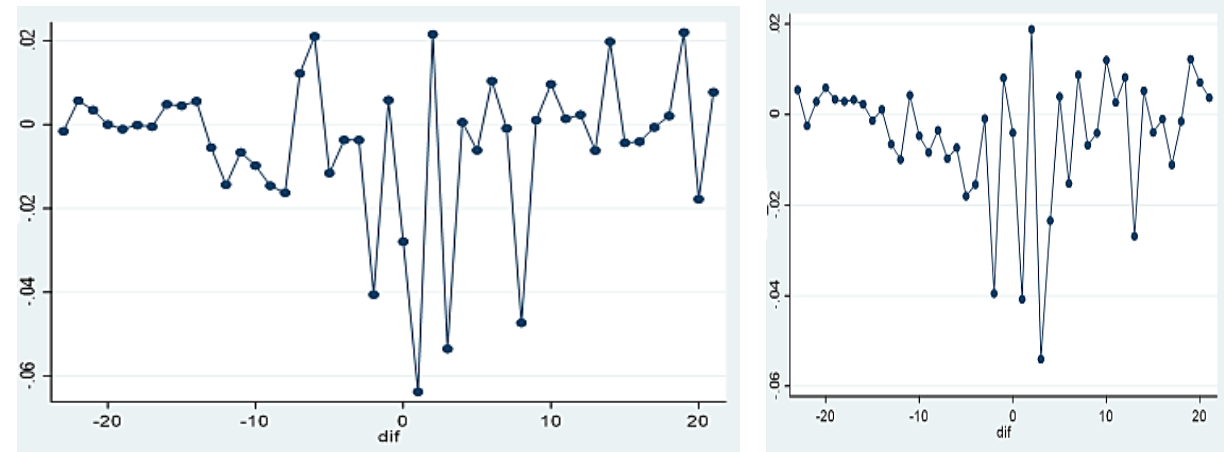

Panel B. AARs in non-Eurozone countries versus Eurozone countries
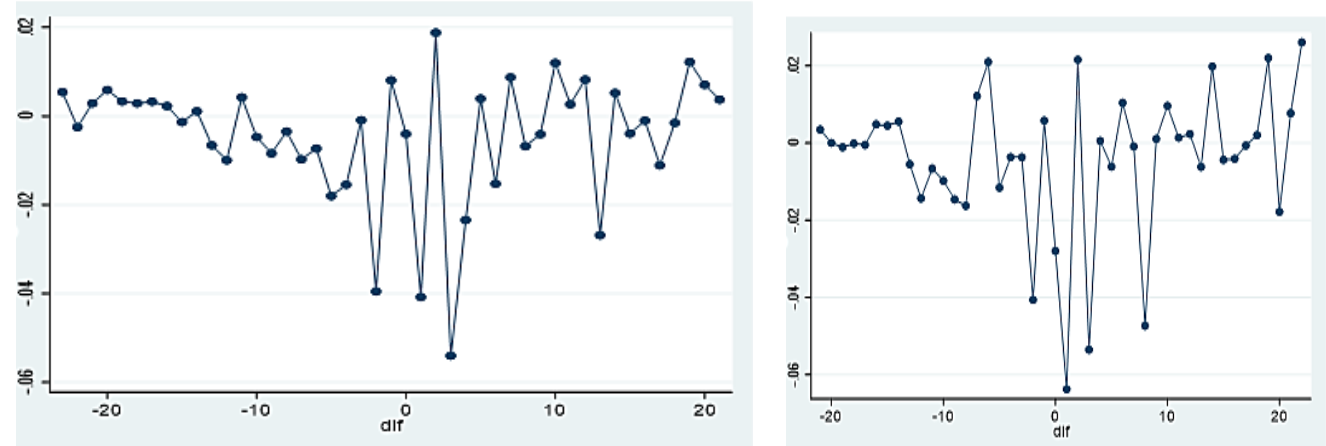

Figure 2 Average abnormal returns by world-systems theory and eurozone membership

The figure reports the evolution of AARs on $[-20 ; 20]$ window, day 0 representing the official announcement of the coronavirus pandemic. The top two graphs present the AARs for the periphery (and semi-periphery) countries and the core countries, respectively. The bottom section illustrates the AARs for the eurozone countries and the non-eurozone countries, respectively. The ARs are computed using the market model.

The graphs from Figure 2 depict the AARs for banks from core countries versus periphery and semi-periphery countries. We notice a higher volatility for a longer period of time for banks from periphery and semi-periphery countries, 
compared to banks from core countries. Regarding the banks from non-eurozone countries and eurozone countries, the findings reflect that for the ones from noneurozone countries, the volatility is higher, similarly to periphery and semiperiphery countries.

\subsection{Comparison between average abnormal returns by regulatory and supervisory factors}

In order to identify the differences between banks from a regulatory perspective, we use the banking regulation and supervisory measures available for the public in a database created through the Barth, Caprio and Levine (2013) questionnaire.

We use three main indices in our study: overall activity restriction index, supervisory power index and overall capital stringency index. The overall activity restriction index measures the extent to which the bank can engage in securities transactions, real estate transactions, insurance activities and the possibility of owning nonfinancial firms, higher values indicating grater restrictiveness; the supervisory power index measures the degree to which the supervisory authorities have the power to take specific action for preventing and correcting reasons, higher values indicating grater supervisory power and the overall capital stringency index measures whether the capital requirements reflect certain risks and deducts certain market value losses before determining minimum capital adequacy, higher value meaning grater stringency (Barth, Caprio, and Levine, 2013).

The table reports cumulated average abnormal returns for sub-groups divided by the median of each index. The first two lines report the CAARs calculated by overall activity index, the next lines report the CAARs by supervisory power index and overall capital stringency, accordingly. The columns contain the results for each event window. The estimation model used for computing the abnormal returns is the market model ${ }^{1}$.

Table 8 Cumulated average abnormal returns by regulation

\begin{tabular}{llllll} 
CAAR & CAAR & CAAR & CAAR & CAAR & CAAR \\
$(-1,1)$ & $(-3,3)$ & $(-5,5)$ & $(0,0)$ & $(1,1)$ & $(1,5)$ \\
\hline
\end{tabular}

Overall activity restriction

index

\begin{tabular}{|c|c|c|c|c|c|c|}
\hline \multirow[t]{2}{*}{ Low activity restriction } & $-0.0438^{* * *}$ & $-0.1584^{* * *}$ & $-0.2155^{* * *}$ & $-0.0180^{* * * *}$ & $-0.0445^{\text {*** }}$ & $-0.1495^{* * * *}$ \\
\hline & 0.0004 & 0.0000 & 0.0000 & 0.0027 & 0.0000 & 0.0000 \\
\hline High activity restriction & $-0.0500^{* * *}$ & $-0.1523^{\text {**** }}$ & $-0.2103^{* * * *}$ & $-0.0142^{* * *}$ & $-0.0500^{* * *}$ & $-0.1249^{* * *}$ \\
\hline
\end{tabular}

${ }^{1}$ Folozind modelul CAPM am obținut rezultate similare. 


\begin{tabular}{|c|c|c|c|c|c|c|}
\hline & $\begin{array}{l}\text { CAAR } \\
(-1,1)\end{array}$ & $\begin{array}{l}\text { CAAR } \\
(-3,3)\end{array}$ & $\begin{array}{l}\text { CAAR } \\
(-5,5) \\
\end{array}$ & $\begin{array}{l}\text { CAAR } \\
(0,0) \\
\end{array}$ & $\begin{array}{l}\text { CAAR } \\
(1,1) \\
\end{array}$ & $\begin{array}{l}\text { CAAR } \\
(1,5)\end{array}$ \\
\hline & 0.0000 & 0.0000 & 0.0000 & 0.0074 & 0.0000 & 0.0000 \\
\hline \multirow{2}{*}{$\begin{array}{l}\text { Differences (high activity } \\
\text { restriction - low activity } \\
\text { restriction) }\end{array}$} & -0.0036 & -0.0274 & $-0.0610^{* *}$ & 0.0010 & -0.0024 & $-0.0889^{* * *}$ \\
\hline & 0.8112 & 0.2542 & 0.0358 & 0.8800 & 0.8176 & 0.0002 \\
\hline \multicolumn{7}{|l|}{ Supervisory power index } \\
\hline Low supervisory power & $\begin{array}{l}-0.0454^{* * *} \\
0.0001\end{array}$ & $\begin{array}{l}-0.1674^{* * *} \\
0.0000\end{array}$ & $\begin{array}{l}-0.2152^{* * *} \\
0.0000\end{array}$ & $\begin{array}{l}-0.0117^{* *} \\
0.0410\end{array}$ & $\begin{array}{l}-0.0529^{* * *} \\
0.0000\end{array}$ & $\begin{array}{l}-0.1417^{* * * *} \\
0.0000\end{array}$ \\
\hline High supervisory power & $\begin{array}{l}-0.0472^{* * * *} \\
0.0000\end{array}$ & $\begin{array}{l}-0.1245^{\text {*** }} \\
0.0000\end{array}$ & $\begin{array}{l}-0.1784^{* * * *} \\
0.0000\end{array}$ & $\begin{array}{l}-0.0221^{\text {**** }} \\
0.0000\end{array}$ & $\begin{array}{l}-0.0370^{* * *} \\
0.0000\end{array}$ & $\begin{array}{l}-0.1009^{* * * *} \\
0.0000\end{array}$ \\
\hline \multirow[t]{2}{*}{$\begin{array}{l}\text { Differences (high } \\
\text { supervisory power - low } \\
\text { supervisory power) }\end{array}$} & -0.0037 & $-0.0617^{* * *}$ & $-0.0522^{*}$ & -0.0077 & -0.0142 & $-0.0535^{* *}$ \\
\hline & 0.8027 & 0.0082 & 0.0673 & 0.2328 & 0.1522 & 0.0250 \\
\hline \multicolumn{7}{|l|}{ Overall capital stringency } \\
\hline Low capital stringency & $\begin{array}{l}-0.0539^{* * * *} \\
0.0000\end{array}$ & $\begin{array}{l}-0.1619^{\text {**** }} \\
0.0000\end{array}$ & $\begin{array}{l}-0.2036^{\text {**** }} \\
0.0000\end{array}$ & $\begin{array}{l}-0.0181^{\text {**** }} \\
0.0001\end{array}$ & $\begin{array}{l}-0.0508^{* * *} \\
0.0000\end{array}$ & $\begin{array}{l}-0.1220^{* * *} \\
0.0000\end{array}$ \\
\hline High capital stringency & $\begin{array}{l}0.0901^{\text {** }} \\
0.0226\end{array}$ & $\begin{array}{l}0.0014 \\
0.9835\end{array}$ & $\begin{array}{l}-0.2330^{* * *} \\
0.0042\end{array}$ & $\begin{array}{l}0.0205 \\
0.2849\end{array}$ & $\begin{array}{l}0.0153 \\
0.5633\end{array}$ & $\begin{array}{l}-0.2461^{* * * *} \\
0.0000\end{array}$ \\
\hline \multirow[t]{2}{*}{$\begin{array}{l}\text { Differences (high capital } \\
\text { stringency - low capital } \\
\text { stringency) }\end{array}$} & $-0.1478^{* * *}$ & $-0.1342^{*}$ & 0.0633 & -0.0338 & $-0.0658^{* *}$ & $0.1519^{*}$ \\
\hline & 0.0026 & 0.0901 & 0.5118 & 0.1182 & 0.0487 & 0.0595 \\
\hline
\end{tabular}

Table 8 depicts that regarding the overall activity restriction there are statistically significant differences only on $[-5 ; 5]$ and $[1 ; 5]$ windows, showing a slower reaction of the investors to hearing the announcement. The CAARs indicate an enhanced negative reaction for the banks with a lower activity restriction index. Thus, the investors have a weaker reaction for the banks from countries with a higher activity restriction index. A possible explanation is that the investors perceive the banks from these jurisdictions to be more stable and less affected from the unexpected events. Concerning the supervisory power, we notice an enhanced negative reaction for banks with a lower supervisory power index. Hence, in jurisdictions where the supervisory power is lower, the investors' reaction is stronger, a behaviour that we associate with a reduction in the banking sector's stability and an increased probability of default. We notice statistically significant differences on $[-3 ; 3][-5 ; 5]$ and $[1 ; 5]$ event windows. Regarding the overall capital stringency index, there are statistically significant differences on the following intervals $[-1 ; 1],[-3 ; 3],[1 ; 1]$ and $[1 ; 5]$. We observe that on the last interval, $[1 ; 5]$, investors' reaction on the markets where the capital regulations are 
tighter is much stronger than of those that invest on a market with a lower capital stringency, although the immediate reaction where the capital regulations are tighter is a positive one. Weighting the costs on a longer period of time, the investors expect a tightening of capital requirements in these countries involving higher costs regarding the capital adequacy and therefore, a lower profitability.

From figure 3, we notice that AARs are negative but stronger for banks from countries with lower activity restrictions, which emerges from the interpretation of the graphs as well. Concerning the supervisory power we can observe a similar reaction, the AARs are negative, but stronger for the banks from countries with a lower supervisory power. As for the capital stringency, we notice that the reaction on the markets with tighter capital regulations is more negative compared to markets with tighter capital regulations, although the immediate reaction is positive for those who invest on markets with higher capital stringency.

Panel A. AARs in countries with low versus high activity restrictions
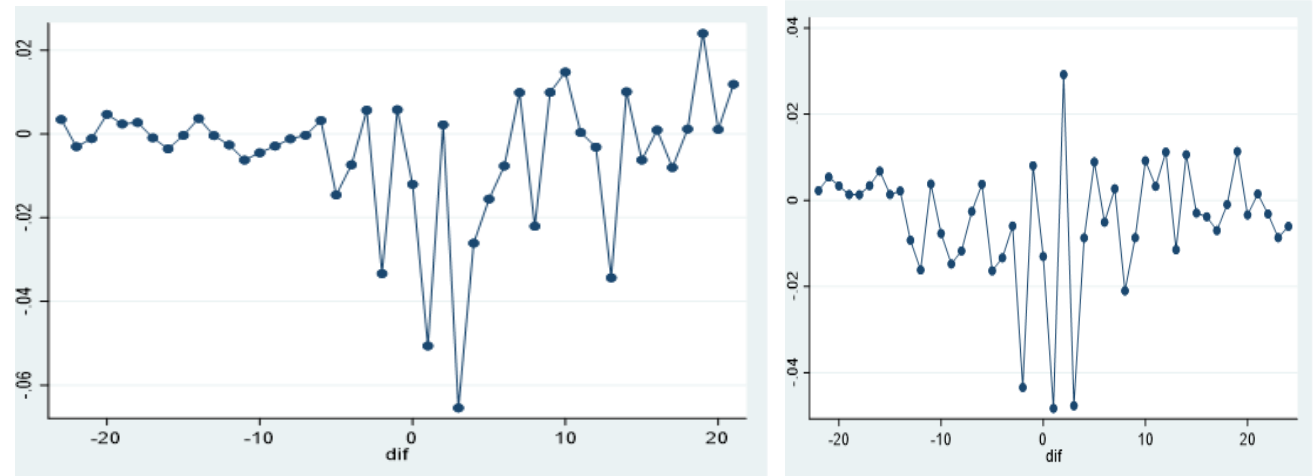

Panel B. AARs in countries with low versus high supervisory power

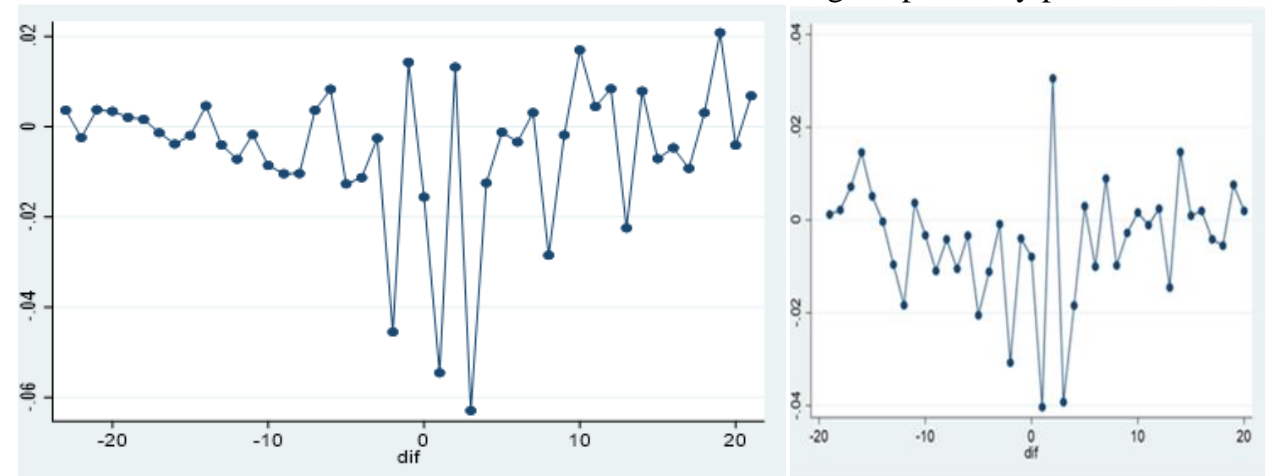


Panel C. AARs in countries with low versus high capital stringency
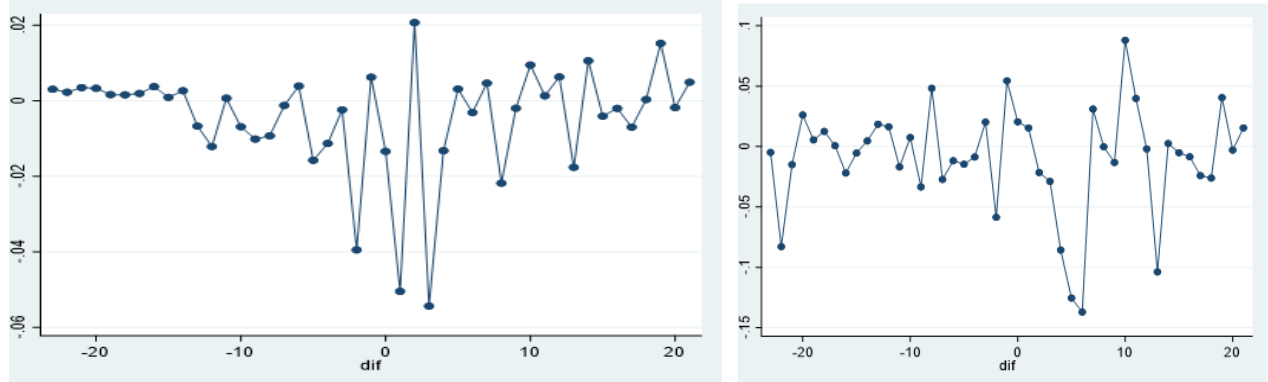

Figure 3 Average abnormal returns by regulation and supervisory indices

The figure presents the AARs evolution on a $[-20 ; 20]$ time frame with day 0 being the official announcement day of the pandemic. The upper graphs show the AARs for countries with low and high activity restriction. In the middle part, the graphs present the AARs for countries with low and high supervisory power index. The last two graphs report the AARs for countries with low and high capital stringency index respectively. The abnormal returns are computed using the market model.

\section{CONCLUSIONS}

In this study, we examine empirically the investors' reaction from the EU banking sector after the official announcement of coronavirus pandemic. We address a topic of current interest regarding the debates on the consequences of the pandemic on world's economy. Applying the event study methodology by computing abnormal returns using two methods for a dataset containing 141 banks from 21 countries, we find that the pandemic has a negative impact concerning the investors' reaction on the stock market from the banking sector. This is associated with a negative impact on the wealth of the banking industry as a result of banks' market value decrease. The results are consistent for all 21 countries involved in the study and for different sub-samples.

However, we notice statistically significant differences between the investors' rection on markets divided by world-systems theory, tax regimes and regulatory and supervisory indices. Investors of banks from non-eurozone countries have an enhanced negative rection than those of banks from eurozone countries. Investors on periphery and semi-periphery markets have stronger negative reaction the those from core countries. From a regulatory perspective, the investors from markets with a lower activity restriction and markets with a lower supervisory power have an enhanced negative reaction, and investors from markets with higher 
capital stringency have a slightly delayed enhanced negative reaction. The main results, according to which the announcement of the pandemic has a negative impact on the banking sector, are consistent throughout our study, regardless of using the hybrid CAPM or the market model.

The results of this study contribute on the debate of the coronavirus pandemic effects on the economy. Meanwhile the overall consequences are obvious and easily observed at a macroeconomic level, we find evidence for the impact of the pandemic on the banking sector with respect for the differences resulted from tax regimes (eurozone membership and world-systems theory classification) and regulatory and supervisory measures.

Acknowledgement: We acknowledge financial support from a grant of the Ministry of Research, Innovation and Digitization, CNCS/CCCDI - UEFISCDI, project number PN-III-P1-1.1-TE-2019-1522, within PNCDI III. 


\section{REFERENCES}

1. Ahir, Hites, Nicholas Bloom and Davide Furceri, IMF Blog (2021), What the Continued Global Uncertainty Means for You, https://blogs.imf.org/2021/01/19/what-the-continued-globaluncertainty-means-for-you/, [Accessed 30.03.2021]

2. Andrieș, Alin Marius, Simona Nistor, Steven Ongena and Nicu Sprincean (2020), "On Becoming an O-SII ("Other Systemically Important Institution”)", Journal of Banking \& Finance, Vol. 111, 105723

3. Baldwin, Richard, Beatrice Weder di Mauro (2020), Economics in the Time of COVID-19, London, Centre for Economic Policy Research

4. Barth, James R., Gerard Caprio, and Ross Levine (2013), "Bank Regulation and Supervision in 180 Countries from 1999 to 2011", Journal of Financial Economic Policy, Vol. 5 No. 2, pp. 111-219

5. Bekaert, Geert, Robert J. Hodrick, and Xiaoyan Zhang (2009), "International Stock Return Comovements", The Journal of Finance, Vol. 64, No. 6, pp. 2591-2626

6. Brown, Stephen J., and Jerold B. Warner (1985), "Using daily stock returns" Journal of Financial Economics, Vol. 14, No, 1, pp. 3-31

7. Chase-Dunn, Christopher, Yukio Kawano, and Benjamin D. Brewer (2000), "Trade globalization since 1795: Waves of integration in the world-system", American sociological review, Vol. 65, No.1, pp. 77-95EUR-Lex (2020), REGULATION (EU) 2020/873 OF THE EUROPEAN PARLIAMENT AND OF THE COUNCIL of 24 June 2020 amending

Regulations (EU) No 575/2013 and (EU) 2019/876 as regards certain adjustments in response to the COVID-19 pandemic, https://eur-lex.europa.eu/legal-

content/EN/TXT/PDF/?uri=CELEX:32020R0873\&from=EN

8. Couppey-Soubeyran, Jézabel, Erica Perego, and Fabien Tripier (2020), "European banks and the Covid-19 crash test", ifo Institute - Leibniz Institute for Economic Research at the University of Munich, EconPol Policy Brief No. 30

9. Demirgüç-Kunt, Asli, Alvaro Pedraza and Claudia Ruiz-Ortega (2021), "Banking sector performance during the covid-19 crisis." Journal of Banking \& Finance, 106305

10. Eichengreen, Barry, Project Syndicate (2020), Coronanomics 101, https://www.projectsyndicate.org/commentary/limits-macroeconomic-tools-coronavirus-pandemic-by-barryeichengreen-2020-

03?utm_source=Project $\% 20$ Syndicate $\% 20$ Newsletter\&utm_campaign=cba7e1c6a1sunday_newsletter_15_03_2020\&utm_medium=email\&utm_term=0_73bad5b7d8-cba7e1c6a193567601\&mc_cid=cba7e1c6a1\&mc_eid=e9fb6cbcc0\&barrier=accesspaylog, [Accessed 15.04.2021]

11. Elnahass, Marwa, Vu Quang Trinh and Teng Li (2021), "Global banking stability in the shadow of COVID-19 outbreak" Journal of International Financial Markets, Institutions and Money, Vol. 72,

12. Goodell, John W (2020), "COVID-19 and finance: Agendas for future research", Finance Research Letters, Vol. 35, 101512

13. Investing.com. (2021), Stock Market Quotes \& Financial News, https://www.investing.com/

14. MacKinlay, A. Craig (1997), "Event Studies in Economics and Finance", Journal of Economic Literature, Vol. 35, No. 1, pp. 13-39

15. Morgan, Donald P., Stavros Peristiani, and Vanessa Savino (2014), "The Information Value of the Stress Test”, Journal of Money, Credit and Banking, Vol. 46, No. 7, pp.1479-1500 
16. Potter, Cristopher (2001), “A history of influenza”, Journal of Applied Microbiology, Vol. 91, No. 4, pp. 572-579.

17. Rizwan, Muhammad Suhail, Ghufran Ahmad, and Dawood Ashraf (2020), "Systemic risk: The impact of COVID-19", Finance Research Letters, Vol. 36, 101682

18. Skrepnek, Grant H., and Kenneth A. Lawson (2001), "Measuring Changes in Capital Market Security Prices: The event study methodology", Journal of Research in Pharmaceutical Economics, Vol. 11, No. 1), pp. 1-17 